\title{
Enzyme activity and morphological change in the spleens of crucian carp in the Yongcheng coal mine subsidence area, China
}

\author{
Y.F. Yan', J.Y. Yang² and J.Y. Lin ${ }^{2}$ \\ ${ }^{1}$ School of Life Sciences, Shangqiu Normal University, Shangqiu, Henan, \\ China \\ ${ }^{2}$ School of Physical Education, Henan Normal University, Xinxiang, Henan, \\ China \\ Corresponding author: J.Y. Yang \\ E-mail: 041146@htu.cn
}

Genet. Mol. Res. 15 (2): gmr. 15027782

Received December 14, 2015

Accepted January 15, 2016

Published April 26, 2016

DOI http://dx.doi.org/10.4238/gmr.15027782

\begin{abstract}
The goal of the current study was to investigate the effects of pollution on aquatic organisms in the Yongcheng coal mine subsidence area. Crucian carp (Carassius auratus) were collected from Yongcheng natural fishpond (experimental group) and Tianmu Lake (control group), and the spleens were isolated for analysis. Subsequently, histological changes, DNA damage, and antioxidant enzyme activity were assessed. The result showed that there were more vacuoles, widened blood sinus cavities, increased partial dot necrosis, and a larger number of brown-yellow nodules in splenic sections stained with hematoxylin and eosin in the experimental group than in the control group. Additionally, it was not easy to distinguish red pulp from white pulp in the experimental group. The antioxidant enzyme activity in the experimental group was significantly lower than that in the control group $(\mathrm{P}<0.01)$. Comet assay results showed varying degrees of tailing and DNA chain breaks in the experimental group, and further analysis demonstrated that the tail length and tail moment
\end{abstract}


were significantly increased compared to those in the control group $(\mathrm{P}<$ $0.01)$. These results suggest that the spleen antioxidant defense system was severely damaged in crucian carp from the Yongcheng coal mine subsidence area.

Key words: Coal mine subsidence area; Crucian carp; Spleen; Enzyme activity; DNA damage

\section{INTRODUCTION}

With the rapid development of the mining industry, land subsidence induced by exorbitant excavation and expansion of mine areas has become one of the most serious geological disasters associated with the coal mine industry. The accumulation of water around mines from different sources including groundwater, coal-gangue leaching water, mine drainage, coal industrial wastewater, and rain can lead to the formation a perennial waterlogged zone (Gong et al., 2009; Zhang et al., 2012), which may result in a series of ecological and environmental problems that severely affect human life, the surrounding environment, and the regional economy in those mining areas (Yang and Liu, 2012). Additionally, the accumulated water can be polluted by dissolved fractions of heavy metals that are lixiviated to the ground and surficial waters.

The Yongcheng mining district is located to the southeast of Shangqiu city in Central China. This abundant coal mine has already become a pillar industry of the national economy in this region. The Yongcheng coal mining subsidence area formed in 2006, covering approximately $30 \mathrm{~km}^{2}$ in area. Natural fishponds formed from accumulated water in this subsidence area, where coal gangue can be found throughout. To date, there has been a limited amount of research assessing the ecological effects of water pollution on fish in this area. Therefore, in the present study, we make the first effort to investigate changes in the morphology and function of spleens in crucian carp (Carassius auratus) from the Yongcheng coal mining subsidence area.

\section{MATERIAL AND METHODS}

\section{Site description}

Control samples were collected from Tianmu Lake $\left(34^{\circ} 35^{\prime} \mathrm{N}, 115^{\circ} 41^{\prime} \mathrm{E}\right)$, which is located to the north of Shangqiu city in Central China. Widespread wetlands and grasslands in the Yellow River valley supply a good habitat for aquatic organisms and birds, and the Tianmu Lake Nature Reserve is considered to be free of pollution.

Experimental samples were collected from a natural fishpond in Liugang Village, Shibali Town $\left(33^{\circ} 57^{\prime} \mathrm{N}, 116^{\circ} 21^{\prime} \mathrm{E}\right)$ in the Yongcheng coal mining subsidence area, which is located to the southeast of Shangqiu city. All experiments involving fish were conducted following the guidelines of the Animal Ethics Committee, Henan Province Animal Institute, China.

\section{Animal collection}

All crucian carps were collected by net with the help of local fishermen. Experimental 
crucian carps had and average weight of $0.20 \pm 0.18 \mathrm{~kg}$ and length of $20.8 \pm 2.3 \mathrm{~cm}$. Control crucian carps had an average weight of $0.24 \pm 0.18 \mathrm{~kg}$ and length of $24.5 \pm 3.6 \mathrm{~cm}$.

\section{Histological examination}

All spleens were removed and fixed in $4 \%$ formaldehyde, processed routinely, and paraffin embedded. Serial sections were stained with hematoxylin and eosin (H\&E) for histological analysis. All sections were observed under a microscope (Eclipse E100, Nikon, Tokyo, Japan).

\section{Sample preparation and enzyme activity analysis}

After spleen removal, $10 \%$ spleen tissue homogenates were prepared in an ice-water bath, and centrifuged at $1000 \mathrm{rpm}$ for $10 \mathrm{~min}$ at $4{ }^{\circ} \mathrm{C}$. Supernatants were then stored at $-80^{\circ} \mathrm{C}$ until enzyme activity analysis. The protein concentration of the supernatants was measured with the Coomassie brilliant blue G250 method. The activities of antioxidant enzyme were evaluated using $\mathrm{Na}^{+} / \mathrm{K}^{+}$-Adenosine Triphosphatase (ATPase) assay kit, Total Superoxide Dismutase (T-SOD) assay kit, CATalase (CAT) assay kit and Glutathione Peroxidase (GSHPx) assay kit (Nanjing Jiancheng Bioengineering Institute, China) according to commercial kit specifications.

\section{Comet assay}

A comet assay (single-cell gel electrophoresis) was carried out according to procedures described by Singh et al. (1988) and Ismail et al. (2014). Briefly, spleens were removed under aseptic conditions, and cells were separated with $0.05 \%$ collagenase (Sigma-Aldrich, St. Louis, MO, USA). Single spleen cells $\left(1 \times 10^{5}\right.$ cells $\left./ \mathrm{mL}\right)$ were mixed with low-melting-point agarose, and layered on an agarose pre-coated slide. The slides were immersed in freshly prepared Triton lysis buffer, $\mathrm{pH} 10$, and then placed in electrophoresis buffer $(\mathrm{NaOH}, \mathrm{pH}>13)$ for DNA denaturation. Subsequently, the electrophoresis was performed in the same alkaline solutions for $30 \mathrm{~min}$ at $25 \mathrm{~V}$. The slides were then stained with ethidium bromide and observed under a fluorescent microscope (Eclipse E100, Nikon), and the tail length was measured by Comet Assay Software Project (CASP) image analyzer software (University of Wroclaw, Poland).

\section{Statistical analysis}

Two-tailed Student t-tests were employed to assess the statistical significance of the data. The data are reported as means $\pm \mathrm{SD} . \mathrm{P}<0.01$ was considered to be statistically significant.

\section{RESULTS}

\section{Histological changes}

The results of the H\&E staining (Figure 1) revealed that there was distinct white and red pulp in the control group. In contrast, the results of the experimental group showed deeper 
color, more vacuoles, wider blood sinus cavities, lymphocyte necrosis, and had numerous brown nodules. Additionally, serious splenorrhagia was observed in some areas, which results in red blood cell-filled spleens such that red pulp cannot be distinguished from white pulp.

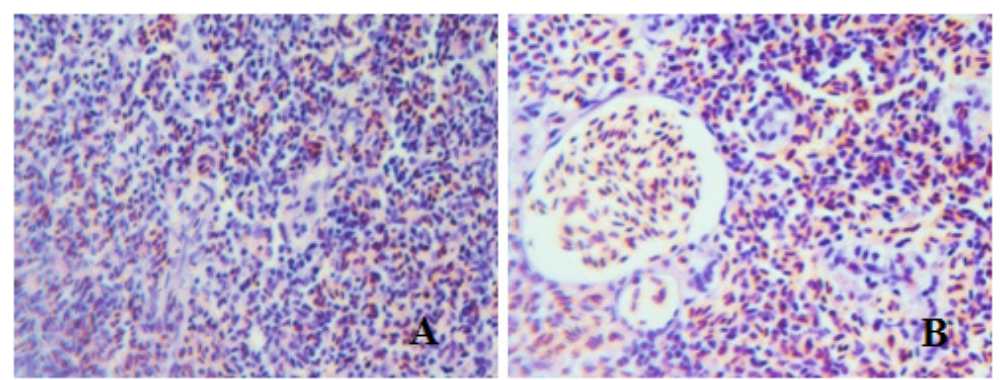

Figure 1. H\&E staining of spleen morphology (400X). A. Experimental group. B. Control group.

\section{Enzyme activity}

The activities of SOD, CAT, GSH-Px, and $\mathrm{Na}^{+} / \mathrm{K}^{+}$-ATPase in the experimental group were $102.75 \pm 3.7 \mathrm{U} / \mathrm{mg}, 12.49 \pm 0.67 \mathrm{U} / \mathrm{mg}, 388.6 \pm 11.92 \mathrm{U} / \mathrm{mg}$, and $4.71 \pm 0.24 \mu \mathrm{mol}$ $\mathrm{Pi} \cdot \mathrm{mg}^{-1} \cdot \mathrm{h}^{-1}$, respectively. In contrast, the activities of SOD, CAT, GSH-Px, and $\mathrm{Na}^{+} / \mathrm{K}^{+}$-ATPase in the control group were $126.83 \pm 2.74 \mathrm{U} / \mathrm{mg}, 18.57 \pm 0.62 \mathrm{U} / \mathrm{mg}, 527.85 \pm 8.95 \mathrm{U} / \mathrm{mg}$, and $6.14 \pm 0.19 \mu \mathrm{mol} \mathrm{Pi} \cdot \mathrm{mg}^{-1} \cdot \mathrm{h}^{-1}$, respectively. As shown in Figure 2, the enzyme activities of the experimental group were significantly lower than those of the control group $(\mathrm{P}<0.01)$.
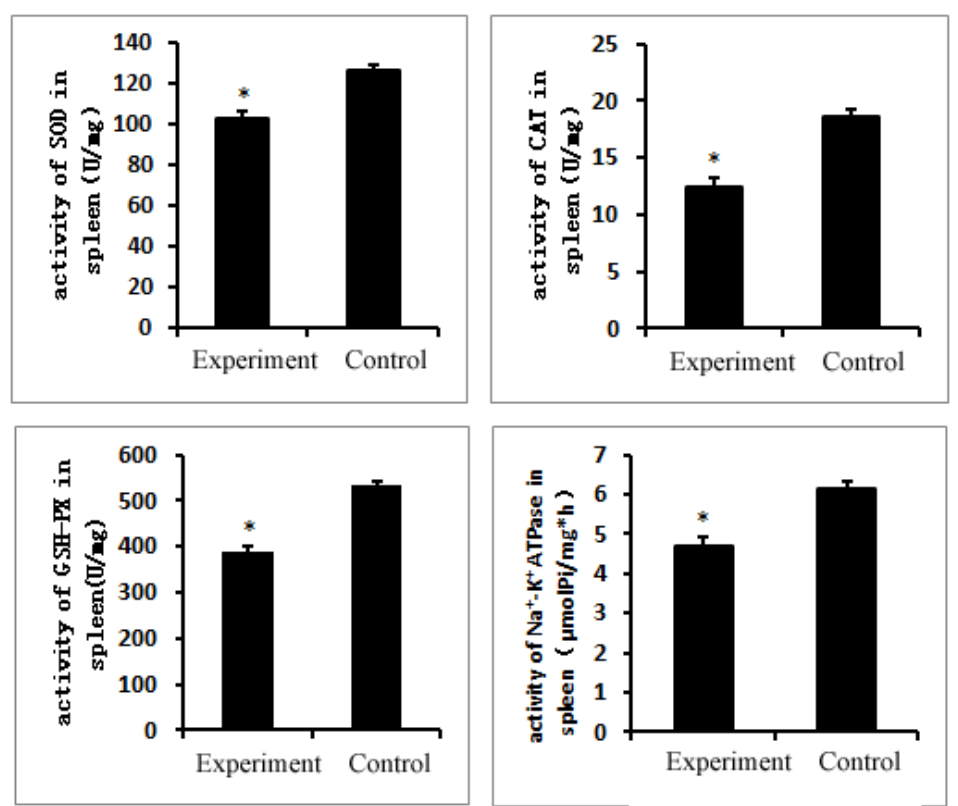

Figure 2. Enzyme activities of SOD, CAT, GSH-PX, and ATPase in crucian carp (Carassius auratus) spleens. ${ }^{*} \mathrm{P}<0.01$. 


\section{Comet assay analysis}

Crucian carp spleen cell nuclei in the control group were rounded with neat margins and had red, uniform fluorescence intensity as observed under fluorescence microscopy (Figure 3A). The cells of crucian carp spleens in the experimental group were damaged to varying degrees with broken DNA chains, and thus the results showed dispersed fluorescence and with classic comet tails (Figure 3B). Moreover, CASP analysis showed that the DNA from spleens in the experimental group was seriously damaged, with double-stranded DNA breaks, and the fragments formed a clear tail, whereas no such tail was observed in the control group (Figure 3C and D). The head DNA \% (HDNA\%) and head length (HL) were lower in the experimental group $(\mathrm{P}<0.01)$ than in the control group, while the tail DNA \% (TDNA\%), tail length (TL), tail moment (TM), and Olive tail moment (OTM) were significantly higher in the experimental group $(\mathrm{P}<0.01)$ (Table 1$)$.

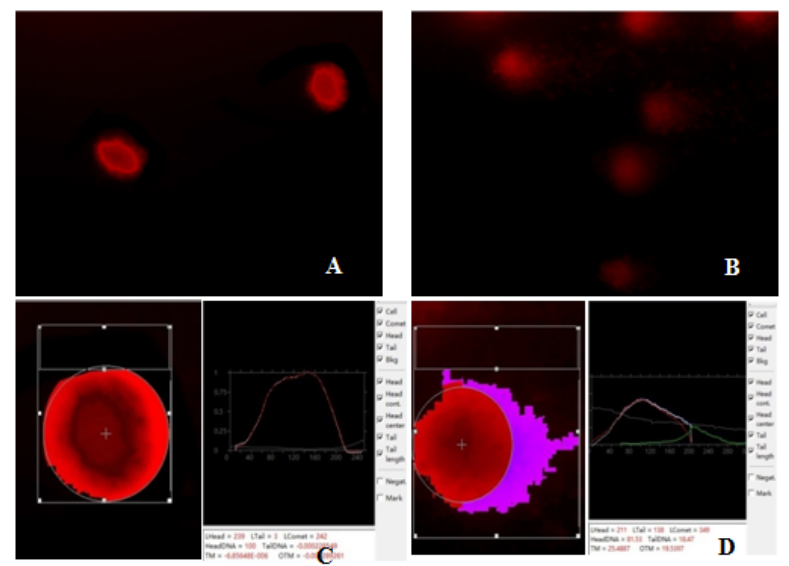

Figure 3. Comet assay images of spleen cells from crucian carp (Carassius auratus) (400X). A. Experiment group. B. Control group. C. and D. CASP software analysis of images A and B, respectively.

Table 1. DNA damage in the spleen cell nuclei of crucian carp (Carassius auratus) (means $\pm \mathrm{SD}, \mathrm{N}=10$ ).

\begin{tabular}{l|c|c|c|c|c|c|c|c}
\hline & Cells & HDNA\% & TDNA\% & CL $(\mu \mathrm{m})$ & HL $(\mu \mathrm{m})$ & TL $(\mu \mathrm{m})$ & TM $(\mu \mathrm{m})$ & OTM $(\mu \mathrm{m})$ \\
\hline Control group & 100 & $96.8 \pm 0.7$ & $3.1 \pm 0.7$ & $209.8 \pm 9.8$ & $199.1 \pm 7.9$ & $20.6 \pm 4.4$ & $0.9 \pm 0.4$ & $3.1 \pm 0.7$ \\
\hline Experiment group & 100 & $89.2 \pm 0.6^{*}$ & $8.7 \pm 0.6^{*}$ & $212.7 \pm 11.2$ & $176.7 \pm 7.8^{*}$ & $35.9 \pm 4.2^{*}$ & $2.4 \pm 0.4^{*}$ & $5.3 \pm 0.7^{*}$ \\
\hline
\end{tabular}
$* \mathrm{P}<0.01$

\section{DISCUSSION}

Heavy metals from mining effluents have a severe impact on the health and ecological integrity of aquatic ecosystems (Schmitt et al., 2007), and has thus become a major concern of the public and scientific community (Vutukuru, 2005; Guan et al., 2014). Aquatic organisms respond to changes in their environment, and the responses in turn reflect the prevailing health status of the aquatic ecosystem (Qadir et al., 2008; Qadir and Malik, 2011). Our preliminary assessment of water collected from the experimental site revealed that it contained heavy metals such as $\mathrm{Cr}, \mathrm{Pb}$, and $\mathrm{Cd}$ at higher concentrations than those at the control site $(\mathrm{P}<0.01$, data not shown). 
Fish are sensitive to heavy metal contamination, and toxic levels of heavy metals can have apparent chronic and/or lethal effects (Wright and Welbourn, 2002). Therefore, fish are often used as sensitive bio-indicators of trace element pollution to evaluate the health of aquatic ecosystems (Dórea, 2008; Bharti and Banerjee, 2011; Al Sayegh Petkovšek et al., 2012). Heavy metals are concentrated at different levels in different organs of the body (Chi et al., 2007), and evaluation of these levels is considered important for understanding the health of an organism (Buggy and Tobin, 2008; Ayotunde et al., 2012). In the present study, the spleens of wild crucian carp (Carassius auratus) were used to assess pollution levels, which may reflect the population effect on fish induced by water pollution.

Many different environmental pollutants can damage the immunologic functions of fish and decrease their resistance to disease (McLeay, 2000; Tiwary, 2001). The physiological and biochemical metrics of the spleen are important for the assessment of the toxicological effects of pollutants because they are sensitive and easily affected by heavy metals (Feng et al., 2006). Additionally, the activities of antioxidant enzymes reflect splenic function. For example, GSHPx plays an important role in the detoxification system through clearing peroxide metabolites from cells and relieving DNA damage (van der Oost et al., 2003; Lima et al., 2006). In the current study, we found that the activities of SOD, CAT, GSH-Px, and $\mathrm{Na}^{+} / \mathrm{K}^{+}$-ATPase were significantly decreased in the spleens of crucian carp from the Yongcheng coal mine subsidence area compared to those in control spleens. These results suggest that heavy metals have inhibited antioxidant enzyme activity in spleens, which may be related to damage membranous structures of splenic cells that limit their detoxification and metabolic capabilities.

Heavy metals enter the cytosol through compromised cell membranes and activate calcium channels in the endoplasmic reticulum and mitochondria, which then trigger DNA breakage and apoptosis. Spleen morphological structures were seriously damaged, and DNA chains were broken in the experimental group herein.

In conclusion, the spleen antioxidant defense system, splenic histological structures, and spleen cell DNA were all seriously damaged in crucian carp from the Yongcheng coal mine subsidence area. Taken together, these results provide important information for controlling and managing water pollution due to heavy metals, and for assessing water suitability for domestic and agricultural use.

\section{Conflicts of interest}

The authors declare no conflict of interest.

\section{ACKNOWLEDGMENTS}

Research supported by the 2015 Foundation Project of Henan Federation of Social Science (\#315).

\section{REFERENCES}

Al Sayegh Petkovšek S, Mazej Grudnik Z and Pokorny B (2012). Heavy metals and arsenic concentrations in ten fish species from the Šalek lakes (Slovenia): assessment of potential human health risk due to fish consumption. Environ. Monit. Assess. 184: 2647-2662. http://dx.doi.org/10.1007/s10661-011-2141-4

Ayotunde EO, Offem BO and Ada FB (2012). Heavy metal profile of water, sediment and freshwater cat fish, Chrysichthys nigrodigitatus (Siluriformes: Bagridae), of Cross River, Nigeria. Rev. Biol. Trop. 60: 1289-1301. 
Bharti S and Banerjee TK (2011). Bioaccumulation of metals in the edible catfish Heteropneustes fossilis (Bloch) exposed to coal mine effluent generated at Northern Coalfield Limited, Singrauli, India. Bull. Environ. Contam. Toxicol. 87: 393-398. http://dx.doi.org/10.1007/s00128-011-0371-3

Buggy CJ and Tobin JM (2008). Seasonal and spatial distribution of metals in surface sediment of an urban estuary. Environ. Pollut. 155: 308-319. http://dx.doi.org/10.1016/j.envpol.2007.11.032

Chi QQ, Zhu GW and Alan L (2007). Bioaccumulation of heavy metals in fishes from Taihu Lake, China. J. Environ. Sci. (China) 19: 1500-1504. http://dx.doi.org/10.1016/S1001-0742(07)60244-7

Dórea JG (2008). Persistent, bioaccumulative and toxic substances in fish: human health considerations. Sci. Total Environ. 400: 93-114. http://dx.doi.org/10.1016/j.scitotenv.2008.06.017

Feng H, Cheng J, Luo J, Liu SJ, et al. (2006). Cloning of black carp b-actin gene and primarily detecting the function of its promoter region. Acta Genet. Sinica 33: 133-140. http://dx.doi.org/10.1016/S0379-4172(06)60032-2

Gong SL, Li C and Yang SL (2009). The microscopic characteristics of Shanghai soft clay and its effect on soil body deformation and land subsidence. Environ. Geol 56: 1051-1056. http://dx.doi.org/10.1007/s00254-008-1205-4

Guan Y, Shao C and Ju M (2014). Heavy metal contamination assessment and partition for industrial and mining gathering areas. Int. J. Environ. Res. Public Health 11: 7286-7303. http://dx.doi.org/10.3390/ijerph110707286

Ismail M, Khan QM, Ali R, Ali T, et al. (2014). Genotoxicity of chlorpyrifos in freshwater fish Labeo rohita using Alkaline Single-cell Gel Electrophoresis (Comet) assay. Drug Chem. Toxicol. 37: 466-471. http://dx.doi.org/10.3109/014805 $\underline{45.2014 .887093}$

Lima PL, Benassi JC, Pedrosa RC, Dal Magro J, et al. (2006). Time course variations of DNA damage and biomarkers of oxidative stress in tilapia (Oreochromis niloticus) exposed to effluents of a swine industry. Arch. Environ. Contam. Toxicol. 50: 23-30.

McLeay G (2000). The nemesis of quackery. BMJ. Clin. Res. 321: 9401-9408.

Qadir A and Malik RN (2011). Heavy metals in eight edible fish species from two polluted tributaries (Aik and Palkhu) of the River Chenab, Pakistan. Biol. Trace Elem. Res. 143: 1524-1540. http://dx.doi.org/10.1007/s12011-011-9011-3

Qadir A, Malik RN and Husain SZ (2008). Spatio-temporal variations in water quality of Nullah Aik-tributary of the river Chenab, Pakistan. Environ. Monit. Assess. 140: 43-59. http://dx.doi.org/10.1007/s10661-007-9846-4

Schmitt CJ, Brumbaugh WG and May TW (2007). Accumulation of metals in fish from lead-zinc mining areas of southeastern Missouri, USA. Ecotoxicol. Environ. Saf. 67: 14-30. http://dx.doi.org/10.1016/j.ecoenv.2006.11.002

Singh NP, McCoy MT, Tice RR and Schneider EL (1988). A simple technique for quantitation of low levels of DNA damage in individual cells. Exp. Cell Res. 175: 184-191. http://dx.doi.org/10.1016/0014-4827(88)90265-0

Tiwary RK (2001). Environmental impact of coal mining on water regime and its management. Water Air Soil Pollut. 132: 185-199. http://dx.doi.org/10.1023/A:1012083519667

van der Oost R, Beyer J and Vermeulen NP (2003). Fish bioaccumulation and biomarkers in environmental risk assessment: a review. Environ. Toxicol. Pharmacol. 13: 57-149. http://dx.doi.org/10.1016/S1382-6689(02)00126-6

Vutukuru SS (2005). Acute effects of hexavalent chromium on survival, oxygen consumption, hematological parameters and some biochemical profiles of the Indian major carp, Labeo rohita. Int. J. Environ. Res. Public Health 2: 456-462. http://dx.doi.org/10.3390/ijerph2005030010

Wright DA and Welbourn P (2002). Environmental toxicology. Cambridge environmental chemistry series 11, University Press, Cambridge, UK.

Yang Q and Liu WS (2012). The study on land reclamation technology and ecological control for coal mining subsidence area. Adv. Mat. Res. 446-449: 2973-2977.

Zhang Y, Feng Q, Meng Q, Lu P, et al. (2012). Distribution and bioavailability of metals in subsidence land in a coal mine China. Bull. Environ. Contam. Toxicol. 89: 1225-1230. http://dx.doi.org/10.1007/s00128-012-0828-Z 